\title{
Surgical Results of coronary artery bypass grafting without cardiopulmonary bypass - Analysis of 3,410 patients
}

Resultados cirúrgicos na revascularização do miocárdio sem circulação extracorpórea: análise de 3.410 pacientes

Ricardo de Carvalho LIMA, Mozart Augusto Soares ESCOBAR, José Glauco LOBO FILHO, Roberto DINIZ, Antonio SARAIVA, Antonio CÉSIO, Mário GESTEIRA, Frederico VASCONCELOS

Abstract

Objective: Over the past few years, great strides have been made in off-pump coronary surgery. This progress is due to a combination of the advances in surgical techniques and the development of instruments that make it possible to perform this procedure in the most varied situations. This is a retrospective study, the purpose of which is to assess our experience with this procedure over the last eleven and a half years. The authors underscore the rapid progress of the method in recent years and report on its indications, contraindications and results.

Methods: In the period from August 1991 to December 2003, 3,410 consecutively patients suffering from angina pectoris were submitted to off-pump coronary surgery. Ages ranged from 13 to 93 years, with a mean of $63 \pm 12.0$ years. Males accounted for $58 \%$ of the cases. The angina was rated according to the criteria of the Canadian Cardiovascular Society, $6.1 \%$ of the patients being in Class $\mathrm{I}, 6.8 \%$ in Class II, $46.3 \%$ in Class III and $40.8 \%$ in Class IV.

Results: Intraoperative mortality was low $(0.4 \%)$. Hospita mortality (30 postoperative days) was $\mathbf{2 . 5 \%}$. Mortality and morbidity among the octogenarian patients were extremely low compared with patients operated on with cardiopulmonary bypass (CPB) $(2.2 \%$ versus $12.6 \%)(p<0.001)$. Postoperative complications regarded as nonfatal occurred in $7.6 \%$. In the final year no difference was observed between the number of conduits in the patients operated on with and without CPB [with CPB $2.8 \pm 1.2$ and without $2.8 \pm 0.8$ (NS)]. Acute myocardial infarction was the most frequent complication, occurring in $2.7 \%$ of the patients. The mean time in the intensive care unit was 22.3 hours.

Conclusions: Off-pump coronary surgery, employed as a revascularization technique in patients requiring multiple grafts, is a reproducible procedure, the results of which are similar to those obtained from conventional surgery with CPB. In the present series it was possible to perform coronary artery bypass grafting without CPB in $95 \%$ of the patients, thus making all patients with indication for grafting potential candidates for the procedure without $\mathrm{CPB}$.

Descriptors: coronary disease, coronary artery bypass grafting; off-pump coronary surgery.

\footnotetext{
Medical School / Oswaldo Cruz University Hospital - UPE; Unitórax - Real Hospital do Coração, PE and Icorp, CE, Brazil. Rua Arnóbio Marques, 310 - Santo Amaro - Recife, - PE. CEP 50.100-130

Correspondence address: Ricardo de Carvalho Lima Rua dos Navegantes 1515/101- Recife - PE - Brazil CEP: $51.021-010$

E-mail: rclima@elogica.com.br

Work presented in the 30th National Congress of Cardiac Surgery,
} Goiânia - Goiás, Brazil, on 05/03/2003. 


\begin{abstract}
Resumo
Objetivo: Nos últimos anos, tem-se observado um grande avanço na cirurgia de revascularização miocárdica sem circulação extracorpórea (RMSCEC). Esse desenvolvimento deveu-se à combinação dos avanços da técnica cirúrgica e ao desenvolvimento de instrumentos que possibilitam a realização deste procedimento nas mais variadas situações. Este é um estudo retrospectivo, que visa avaliar nossa experiência com este procedimento nos últimos 11,5 anos. Os autores enfatizam o rápido progresso do método nos últimos anos, suas indicações, contra-indicacõos e resultados. Método: No período de agosto de 1991 e dezembro de 2002, 3.410 pacientes consecutivos, portadores de angina do peito, foram submetidos a cirurgia de revascularização miocárdica sem circulação extracorpórea. A idade variou de 13 a 93 anos ( $63+/-12,0$ anos), sendo $58 \%$ dos pacientes do sexo masculino. $A$ angina foi classificada segundo a Canadian Cardiovascular Society, sendo $6,1 \%$ na classe I, $6,8 \%$ na classe II, $46,3 \%$ na classe III e $\mathbf{4 0 , 8 \%}$ na classe IV.

Resultados: A mortalidade intra-operatória foi baix $(0,4 \%)$. A mortalidade hospitalar (trinta dias de pósoperatório) foi de $2,58 \%$. A mortalidade e morbidade, no grupo
\end{abstract}

\section{INTRODUCTION}

The appearance of cardiopulmonary bypass $(\mathrm{CPB})$ in the last century enabled cardiac surgeons to perform various procedures, which, until then, had not been possible for technical reasons [1]. However CPB triggered a series of inflammatory reactions with different systemic responses, at very different degrees, with the possibility of terminating in death $[2,3]$. In the last few years, there has been a great advance in coronary artery bypass grafting $(\mathrm{CABG})$ without CPB (Off-pump) mainly owing to the combination of advances in the surgical technique [4] and the development of instruments which enable the achievement of this surgery in the most varied situations [5].

There were different points that marked the development of the Off-pump technique. In the initial period (1967-1975) KOLLESSOV [6], ANKENEY [7], TRAPP \& BISARYA [8] presented their experiences and good results. During a period of silence (1967-1981), there was no registration of the procedure being performed. Almost simultaneously, BUFFOLO [9] and BENETTI [10] established a second period with the utilization of this technique and started to divulge their results in the surgical treatment of the anterior arteries of the heart. In a third period (1995-1998), important contributions were observed: revascularization of the dos pacientes octogenários, foram extremamente baixas em relação aos pacientes operados com circulação extracorpórea $(2,2 \% \times 12,6 \%)(p<0,001)$. As complicações pós-operatórias que não resultaram em óbito foram de 7,6\%. No último ano, não observamos diferença entre o número de condutos nos pacientes operados com e sem CEC [com CEC 2,8+/-1,2 e sem CEC 2,8+/-0,8 (NS)]. Infarto agudo do miocárdio foi a complicação não fatal mais freqüente, observada em $2,8 \%$ dos pacientes. $O$ tempo médio de permanência na UTI foi de 22,3 horas.

Conclusões: A RMSCEC, usada como técnica de revascularização em pacientes multiarteriais, é um procedimento reproduzível e apresenta resultados semelhantes aos obtidos com a operação convencional com CEC. Nesta série foi possível revascularizar o miocárdio sem circulação extracorpórea em mais de $\mathbf{9 5 \%}$ dos pacientes, tornando assim, a princípio, todos os pacientes, com indicação de revascularização miocárdica, potenciais candidatos à operação de RMSCEC.

Descritores: Coronariopatia, cirurgia. Revascularização miocárdica.

posterior arteries of the heart [11], Off-pump revascularization of the descending aorta by minithoracotomy [12] and the advent of cardiac stabilizers also in 1997 by BOONSTRA, GRANDJEAN \& MARIANI [13].

From this moment several authors reported their experiences with high-risk patients and when compared with a historical series of surgery patients using CPB, presented with a reduction in the postoperative complications observed. In this study, the authors evaluate their experience with this procedure over the last 11 and half years, emphasizing the rapid progression of the method in the last years, its indications and results.

\section{METHODS}

Our experience started in August 1991 and until December 2002, 3,410 patients underwent Off-pump CPBG. The ages ranged from 13 to 93 years (mean $63+-12.0$ years). Patients of eighty or over represented $3.5 \%$ of this cohort and $58 \%$ of the cases were male. Angina was classified according to the Canadian Cardiovascular Society criteria with $6.1 \%$ classified as class I, $6.8 \%$ as class II, $46.3 \%$ as class III and $40.8 \%$ classified as IV. Using the classification of the New York Heart Association, $60.2 \%$ of the patients were class I, $18.7 \%$ class II, $10.8 \%$ class III and $9.3 \%$ were 
class IV. The ejection fraction ranged from 20 to $68 \%$ with an average of $42.3 \%$ and a standard deviation of $17.4 \%$. The demographic data are shown in Table 1.

Table 1. General data of the patients $(n=849)$

\begin{tabular}{lcc}
\hline & $(\mathrm{n})$ & $\%$ \\
\hline Age (years) $>70$ & 187 & 22,08 \\
Smokers & 627 & 73,88 \\
Hypertension & 537 & 63,24 \\
Dyslipidemia & 436 & 51,38 \\
Diabetes & 550 & 64,74 \\
Previous AMI & 464 & 54,65 \\
peripheral vascular disease & 81 & 9,55 \\
Stroke & 141 & 16,60 \\
Obesity & 160 & 18,90 \\
dialysis & 30 & 3,53 \\
Obstructive pulmonary disease & 158 & 18,64 \\
Coronary arterial disease & & \\
1 vessel & 134 & 15,78 \\
2 vessels & 263 & 30,98 \\
3 vessels & 452 & 53,21 \\
\hline AMI Acu
\end{tabular}

AMI - Acute myocardial infarction

\section{Operative technique}

The surgeries were performed by longitudinal median sternotomy. The left internal thoracic artery (LITA) and the saphenous vein (SV) were dissected and simultaneously prepared for use. Since 1998, all the cases were operated on with the assistance of cardiac stabilization and shunts. We utilized the CTS-Guidant platform. The pericardium was opened in the form of an 'I'. Heparization was employed in two different doses: 1) $2 \mathrm{mg} / \mathrm{kg} /$ weight to perform a maximum of two grafts and 2) $4 \mathrm{mg} / \mathrm{kg} /$ weight to perform three or more grafts. Heparization was controlled by the activated coagulation time (ACT) with 300 seconds being accepted as the minimum value. The grafts on the pericardium were placed according to the previously described technique [4] (Figure 1). Anastomoses were performed according to the following order: anterior descending coronary, diagonal, right coronary and finally the marginal branches of the circumflex artery (Figure 2.). The distal anastomosis was performed before the proximal in the majority of the patients. A prolene 5-0 thread was used as a type of tourniquet on the proximal portion of the vessel to be treated with the aim of temporarily occluding the vessel whilst the coronary perfusor (shunt) is put in place, which ranged from $1.5 \mathrm{~mm}$ to $2.5 \mathrm{~mm}$ in diameter. Heparin was neutralized at the end of the procedure using a 1:1 proportion.

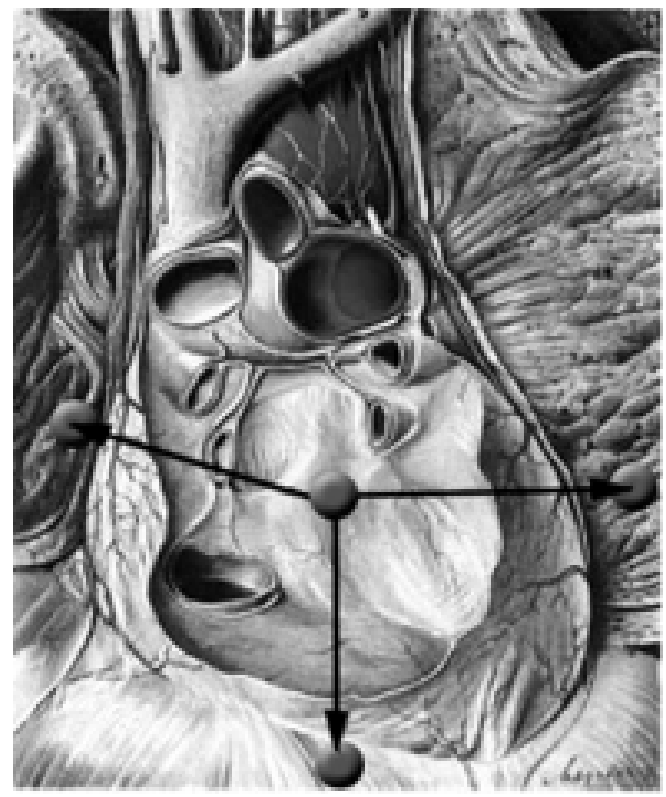

Fig. 1 -Ilustrative diagram of the suture on the posterior pericardium

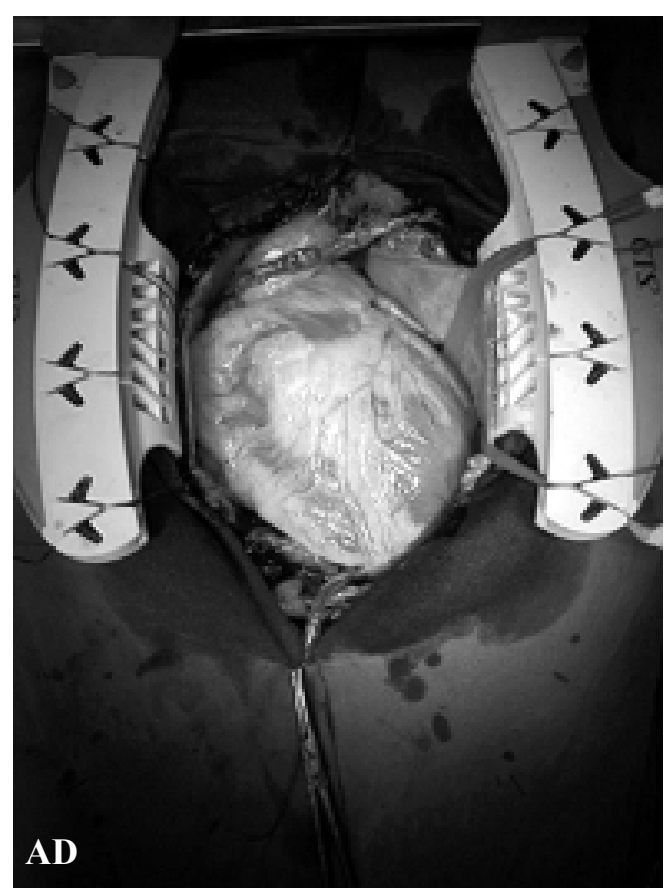



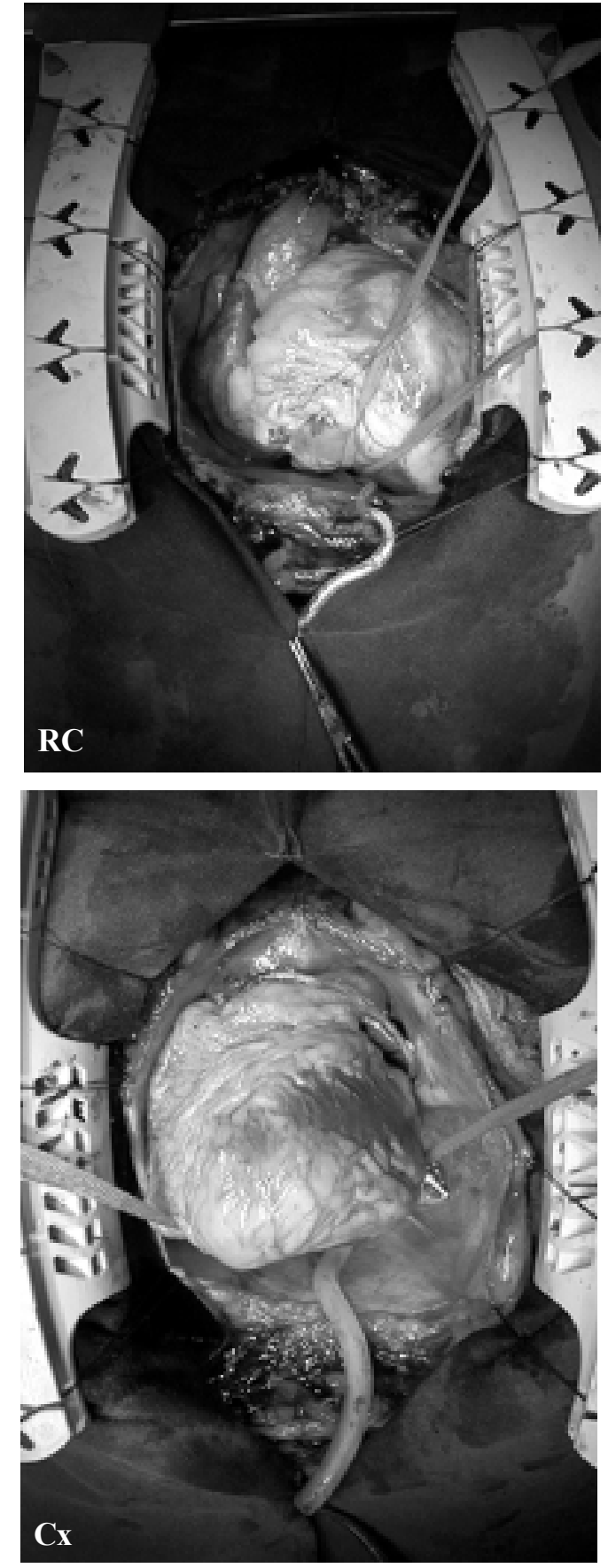

Fig. 2 - Exposure of the heart during off-pump coronary artery bypass grafting

$\mathrm{AD}=$ anterior descendente artery; $\mathrm{RC}=$ right coronary artery; $\mathrm{Cx}=$ Circumflex artery

\section{Surgical indication}

Over these years three distinct periods were observed:

1) initial $(1991$ - 1993) where the surgery was reserved for severe patients or patients who presented with isolated coronary lesions of the anterior wall of the heart.

2) A second period (1993 - 1998) the posterior arteries were also revascularized in patients with good arteries and a good ventricle.

3) The third period $(1998-2003)$ all the patients considered to have indications for conventional surgery, were also considered for Off-pump surgery (Figure 3.).

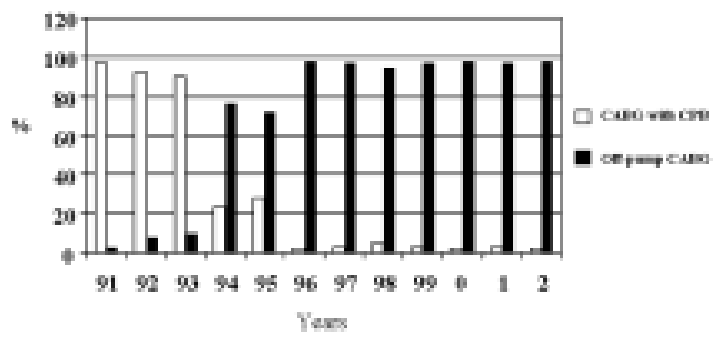

Fig. 3 - Evolution of CABG with CPB and Off-pump CABG over the years $(1991-2002)$

Currently we also consider some conditions as absolute contra-indications: combined surgery (revascularization and valve surgery); The presence of severe arrhythmias and significant heart failure.

Other contra-indications were relative and generally, observed during the operation: intramyocardial coronary; arteries of less than $1.2 \mathrm{~mm}$ diameter; arteries with intense calcification and big hearts with low ventricular function.

Some patients were considered ideal for Off-pump CPBG: advanced ages; previous strokes; renal failure; low ejection fraction, hematological alterations, arteriosclerotic plaques in the aorta and femoral artery, some reoperations and the presence of malignant diseases.

The results were expressed as a mean \pm standard error. Statistical analysis of the data was made using the student $\mathrm{t}$-test. The values were considered as statistically significant when the $\mathrm{p}$-value $<0.05$.

\section{RESULTS}

The utilization of Off-pump CPBG increased over the years from $3 \%$ in $1991,10 \%$ in 1993 to $72 \%$ in 1995 . From 1998 until now this percentage has remained greater than $95 \%$, and for long periods it has been $100 \%$ (Figure 3 ). A total of 6,664 anastomosis were performed with 3,752 (56.3\%) venous grafts and 2,912 (43.7\%) arterial grafts. Of the arterial 
grafts utilized the mammary artery represented $95.9 \%(2,792$ grafts), the radial artery $3.8 \%$ (111 grafts) and the gastroepiploic artery $0.3 \%$ ( 9 grafts). In the last year we did not observe any significant difference between the number of grafts of $\mathrm{CPB}$ and off-pump patients (CPB 2.8 \pm 1.2 and off-pump $2.8 \pm 0.8$ ). The circumflex coronary artery was revascularized in 1,292 (37.9\%) of the patients. The average surgery time from the first incision to closure was less than in CPB surgery ( $<31$ minutes). The mean postoperative ventilation time was less in the off-pump patients ( \pm 3 hours and 48 minutes). The mean stay in the intensive care unit was 22 hours and 30 minutes.

\section{Mortality}

The operative mortality was low. In the intra-operative period it was $0.3 \%$ (10 patients) and in the post-operative period it was $2.3 \%$ (78 patients). Thus, the hospital mortality was $2.6 \%$ (88 patients). The causes of death were as follows: acute myocardial infarction, low cardiac outflow syndrome, arrhythmias, stroke, bleeding, sudden death, pulmonary failure, infection, acute renal failure, aortic dissection, pulmonary embolism and other unidentified causes (Table 2 ). Death in the eighty-year-old and over group was extremely low, especially when compared with the patients operated on under $\mathrm{CPB}(2.2 \%$ versus $12.6 \%$ - -value $<0.001)$.

Table 2. Rate of hospital mortality ( 30 days) $(n=3,410)$

\begin{tabular}{lcc}
\hline Cause & (n) & $\%$ \\
\hline AMI & 32 & 0,94 \\
LCOS & 12 & 0,44 \\
Arrhythmia & 8 & 0,29 \\
Stroke & 10 & 0,29 \\
Bleeding & 7 & 0,25 \\
unknown & 7 & 0,25 \\
Sudden death & 3 & 0,11 \\
Pulmonary insufficiency & 3 & 0,11 \\
Sepsis & 2 & 0,07 \\
ARF & 2 & 0,07 \\
Acute dissection of the aorta & 1 & 0,04 \\
Pulmonary embolism & 1 & 0,04 \\
Total & 88 & 2,58 \\
\hline
\end{tabular}

AMI = Acute myocardial infarction, $\mathrm{LCOS}=$ Low cardiac Output Syndrome; ARF $=$ Acute renal failure

\section{Morbidity}

Complications, which were considered important but not fatal, were observed in $262(7.6 \%)$ patients. The most important non-fatal complications in the off-pump CPBG were as follows: atrial fibrillation, acute myocardial infarction, bleeding, stroke, low cardiac output syndrome, pulmonary failure, surgical wound infection and renal failure (Table 3).

Table 3. Non-fatal complications $(n=3,322)$

\begin{tabular}{lcc}
\hline & (n) & $\%$ \\
\hline & & \\
AMI & 93 & 2,8 \\
LCOS & 43 & 1,3 \\
Atrial fibrillation & 56 & 1,7 \\
Stroke & 19 & 0,6 \\
Bleeding & 16 & 0,5 \\
ARF & 21 & 0,6 \\
Pulmonary insufficiency & 6 & 0,2 \\
Infection of operative wound & 8 & 0,2 \\
Total & 262 & 7,6 \\
\hline
\end{tabular}

AMI $=$ Acute myocardial infarction, LCOS $=$ Low cardiac Output Syndrome; $\mathrm{ARF}=$ Acute renal failure

The quantity of transfused blood was low in comparison to patients who underwent operations using $\mathrm{CPB}$ and a large number of patients were operated on without any type of blood transfusion or its derivatives. Only $35.4 \%$ of the patients received blood and/or its derivatives, which signifies that $64.6 \%$ of the patients were not exposed to any type of contamination from blood.

\section{DISCUSSION}

This study of patients represents our entire experience employing off-pump CABG over 11.5 years. This experience includes the initial cases, the learning curve, limitation of revascularization of the posterior vessels of the heart and patients operated on with and without cardiac stabilization $[14,15]$. In this population, there were patients with very different degrees of coronary and systemic diseases (including uni-, bi- and tri-arterial coronary disease), young patients (13 years old) and elderly patients ( 93 years). An average of 2.0 grafts per patient were performed, which for us seemed to be very reasonable, taking into consideration the evolution over 11.5 years, where at the start of the experience coronary angioplasty was not so developed and many patients were submitted to surgical CABG of only one artery. Also it is necessary to consider the learning curve, which in one way or another selected the patients. Over the last years, the mean number of grafts per patient has significantly increased and in the last 631 patients the mean was 2.8 grafts per patient, of which, was not very different to the average number of patients operated on by the conventional technique using CPB. 
The anesthesia, in general, was the same as was used in patients operated on with CPB. However, greater interaction is necessary between the surgeons and the anesthesiologist and, the latter is required more during the procedure. The administration of a lower quantity of anesthetic agents and the utilization of short-duration muscular relaxants enable an earlier extubation of these patients.

The operative technique varied over the years. At the start, cardiac stabilization was achieved using gauze around the heart, the administration of negative chronotropic drugs and proximal and distal tourniquets of the coronary artery. From 1998 we started to systematically use heart stabilizers and intra-coronary shunts. The stabilizers enabled a significant increase in the applicability of the method. The long times of off-pump CABG in 100\% of the patients was possible due to the utilization of these devices. The intra-coronary shunt has also had an important role, not only allowing distal perfusion of the coronary but also reducing the necessity of permanen occlusion using a tourniquet on the coronary artery during anastomosing.

Currently we only use a proximal tourniquet during arteriotomy. The quantity of heparin routinely used is less than that used in conventional $\mathrm{CABG}$ with $\mathrm{CPB}$. We have used 2-4 $\mathrm{mg} / \mathrm{kg} /$ weight and neutralization using protamine sulfate in the proportion of $1: 1$ at the end of the main procedure. In some patients we neutralized in the proportion of $1: 1 / 2$, as these patients had their coagulation systems preserved and can in some situations present with hypercoagulation, which can provoke unsatisfactory results. From 1998, the exposition of the coronary arteries was made associated with a posterior pericardium suture and the utilization of cardiac stabilizers. This modification of the exposure technique was incorporated in our routine surgery and, without doubt enabled off-pump CABG with greater safety and with better access to the coronary arteries.

The surgical practice over the years established three basic positions of exposition of the arteries (anterior descending, right coronary and the circumflex artery). These positions are utilized to avoid serious hemodynamic involvement during the procedure [16]. The delicate maneuvers of exposure of the vessels were achieved with care especially in patients with severe myocardial ischemia. The heart was gradually moved into any position with care and allowed to recover from any initial instability before performing any anastomosis. After exposure of the area of the heart to be approached, the stabilizer is applied and after some minutes any tendency of hypotension is verified. If this happens the heart should be returned to it initial position and attempts to correct any hemodynamic factor, such as low heart rate, must be made.

It seems correct to start anastomosis by the anterior wall of the heart (anterior descending coronary), followed by the right coronary and finally the circumflex artery system and its branches. Revascularization of the anterior descending coronary considerably improves the perfusion of the coronary, enabling and facilitating the revascularization of the posterior arteries. Also performing the proximal anastomosis of the aorta promotes an immediate irrigation of the myocardium soon after the end of the distal anastomosis, facilitating the following anastomosis, as the heart is becoming revascularized.

Off-pump CABG represents a change in the paradigm in the treatment of coronary failure [17]. In the last five years a great amount of interest has been shown for the method and an increase in its applicability across the world. By the number of scientific publications about the theme it is possible to infer that hundreds of centers worldwide currently use this procedure. We believe that candidates for the utilization of this procedure are severely ill patients who possess comorbidities such as: advanced age, previous strokes, renal insufficiency, low ejection fraction, hematological alterations, the presence of plaques in the aorta and femoral artery, recovery and sufferers of malignant diseases.

If this procedure should be recommended for severely ill patients, we believe that low risk patients and patients without comorbidities will also benefit with the same surgical approach. Exceptions exist for those patients with absolute and relative contra-indications. These include combined surgeries (revascularization and valve replacement), severe heart failure, intramyocardial coronary, Arteries of less than $1.2 \mathrm{~mm}$ diameter, coronary arteries with intense calcification (which might result in endo-arteriectomy), severe cardiomegaly with significant ischemia which would not survive the minimum manipulation.

\section{CONCLUSIONS}

The retrospective study demonstrated that, off-pump CABG was used as a revascularization technique in single and multiple graft patients as a routine and uninterrupted procedure for a period of 11.5 years. In this cohort it was possible to perform off-pump CABG in more than $95 \%$ of the patients with a great safety margin. The number of grafts per patient in the last years did not give a significant difference between the patients operated on with or without $\mathrm{CPB}$ and after the learning period this can be the choice procedure for surgical $\mathrm{CABG}$, thus representing a change in the paradigm. 


\section{BIBLIOGRAPHIC REFERENCES}

1. Gibbon Jr JR. Application of a mechanical heart and lung apparatus to cardiac surgery. Minnesota Med 1954; 37:171-85.

2. Carrico CJ. The elusive pathophysiology of the multiple organ failure syndrome. Ann Surg 1993; 218:109-10.

3. Beal AL, Cerra FB. Multiple organ failure syndrome in the 1990s: systemic inflammatory response and organ dysfunction. JAMA 1994; 271:226-33.

4. Lima RC, Escobar M, Lobo Filho JG. Patient selection in offcardiopulmonary bypass revascularization. Heart Surg Forum 2002; 5:229-32.

5. Borst C, Santamore WP, Smedira NG, Bredée JJ. Minimally invasive coronary artery bypass grafting: on the beating heart and via limited access. Ann Thorac Surg 1997; 63(6 suppl):S1-5.

6. Kolessov VI. Mammary artery-coronary artery anastomosis as method of treatment for angina pectoris. J Thorac Cardiovasc Surg 1967; 54: 535-44.

7. Ankeney JL. Coronary vein graft without cardiopulmonary bypass: surgical motion picture In: Annual Meeting of the Society of Thoracic Surgeons, 1972 January.

8. Trapp WG, Bisarya R. Placement of coronary artery bypass graft without pump oxigenator. Ann Thorac Surg 1975; 19:1-9.

9. Buffolo E, Andrade JCS, Succi JE, Leão LE, Cueva C, Branco $\mathrm{JN}$ et al. Revascularização direta do miocárdio sem circulação extracorpórea: descrição da técnica e resultados iniciais. Arq Bras Cardiol 1982; 38: 365-73.
10. Benetti FJ. Direct coronary surgery with saphenous vein bypass without either cardiopulmonary bypass or cardiac arrest. J Cardiovasc Surg 1985; 26: 217-22.

11. Lima R. Revascularization of the circumflex artery without the aid of ECC. In: 12 Encontro dos Discípulos do Dr. EJ Zerbini. Anais Curitiba, Paraná, 1995.

12. Benetti FJ, Ballester C, Sani G, Doonstra P, Grandjean J. Video assisted coronary bypass surgery. J Card Surg 1995; 10:620-5.

13. Boonstra PW, Grandjean JG, Mariani MA. Local immobilization of the left anterior descending artery for minimally invasive coronary bypass grafting. Ann Thorac Surg 1997; 63(6 suppl):S76-8.

14. Lima RC, Escobar M, Wanderley Neto J, Torres LD, Elias DO, Mendonça JT et al. Revascularização do miocárdio sem circulação extracorpórea: resultados imediatos. Rev Bras Cir Cardiovasc 1993; 8: 171-6.

15. Lima RC, Escobar MAS, Diniz R, Franca NAA, Cabral E, Luz J. How much myocardial revascularization can we do without extracorporeal circulation? Heart Surg Forum 2002; 5: 163-7.

16. Lima RC, Escobar MAS, Della Santa RF, Diniz R, D'Aconda G, Bergsland J et al. Avaliação hemodinâmica intra-operatória na cirurgia de revascularização miocárdica sem auxílio da circulação extracorpórea. Rev Bras Cir Cardiovasc 2000; 15 : 201-11.

17. Lobo Filho JG, Dantas MCBR, Rolim JGV, Rocha JA, Oliveira FM, Ciarline $\mathrm{C}$ et al. Cirurgia de revascularização completa do miocárdio sem circulação extracorpórea: uma realidade. Rev Bras Cir Cardiovasc 1997; 12:115-21. 